\title{
Experiential Learning: the field study trip, a student-centred curriculum
}

\author{
Laurence Pattacini \\ University of Sheffield
}

\begin{abstract}
Drawing from student-centred learning theories, this paper identifies key issues related to active participation of students, collaboration and independent learning. It draws from the author's experience of developing and delivering a student-centred curriculum delivered around a field study trip. It explores approaches to active and experiential learning in higher education through the various stages of the curriculum development and the identification of the pedagogical benefits. The student-centred curriculum is part of a professional, accredited course in Landscape Architecture. The field study trip is an opportunity to explore the topics of study actively and in real settings and to learn through hands-on experience - essential to form professionals challenged with making places through planning and design. More generally, the field study trip module is an opportunity to understand the practicalities of embedding experiential learning approaches within higher education. Quotes gathered through an online inquiry provide insight into students' perception and experience.
\end{abstract}

Keywords: experiential learning, active learning, student-centred, co-learning, field study trip.

\section{The field study trip: a catalyst for experiential and active learning}

This paper, drawing as it does from the author's experience in developing and delivering a student-centred curriculum based on a field study trip module (part of a landscape architecture course), illustrates how to engage students in their learning; it provides a practical example of active learning, as promoted in higher education $(\mathrm{HE})$ since the publication of Dewey's seminal book (1938). The student-centred approach to learning and teaching is the subject of numerous research publications and a key principle in contemporary educational ideology (Gibbs, 1981; Brandes and Ginnis, 1986; Bonwell and Eison, 1991; Brown Wright, 2011; Barret, 2010; Slavich and Zimbardo, 2012). It is associated with 'active learning', which Prince (2004, p.223) defines as "any instructional method that engages students in the learning process". Within this broad definition, educational research presents such varied learning approaches as peer-assisted, collaborative, cooperative, problem-based or inquiry-based projects (Bishop and Verleger, 2013). Some researchers group these various learning and teaching principles under the framework of 'Transformational Teaching' aiming at enhancing the students' knowledge and personal development (Mezirow, 2000; Slavich and Zimbardo, op.cit.). Active learning is inherent in the teaching of professional, accredited courses and, more specifically, designfocused courses. The education of design professionals is a complex business, as it combines learning and teaching theoretical principles and their application in practice. It also tries to 
encourage experimental thinking and personal development (Brown et al., 1994). The curriculum is delivered through projects discussed and tested in the design studios, using tutorials and reviews (Kuhn, 2001). Such method implies the integration of multiple skills and knowledge areas; it also aims to encourage a professional attitude to learning by promoting independence, leadership, critical reflection and judgement (Maudsley and Strivens, 2000; Rishbeth, 2007). Reflecting on the field study trip module is an opportunity to explore a practical application of experiential and active learning principles and to provide an example of a studentcentred curriculum.

Experiential learning is championed as a successful and desirable alternative to more traditionally prescriptive and rigid ways of learning (Kraft, 1990; Kolb et al., 2000). It accords with contemporary discourses on empowering students and putting more emphasis on learning processes rather than passive delivery of knowledge (Zuber-Skerritt, 1992). Though there are issues related to the universality and transferability of knowledge acquired through personal experience, there is common agreement that learning through experience has an important role to play in education (Fenwick, 2003). Publications related to Geography (Kent et al., 1997; Healey and Jenkins, 2000; Hope, 2009) argue particularly well that field study trips are ideal for illustrating successful practices in experiential and active learning. Field experience can contribute to more positive attitudes towards and feelings about a topic; it energises students and produces long-lasting learning benefits (Falk and Dierking, 1997; Rishbeth, op.cit; Nadelson and Jordan, 2012; Myers and Jones, 2015).

Freire's study (2012), related to teaching landscape architecture, suggests that field study trips should play a more important role in design courses and, more specifically, in those in landscape architecture. Owen (2006), in his conceptual mapping of thinking context and processes, explains that design is concerned with understanding forms in relation to their effectiveness for functionality and utility as well as their appropriateness in relation to social and cultural factors. The field study trip offers a unique opportunity to experience forms and spaces; it enables students to explore and review the impact and qualities of existing landscape designs; it provides students with a formative experience for developing their design knowledge, understanding and skills. Designers are makers: experiencing places enables them to feed the process of synthesising "what they know [with] new constructions, arrangement, patterns, compositions and concepts that bring tangible, fresh expressions of what can be" (Owen, op.cit., p.17). Visiting existing built environments and design projects is essential to developing an understanding of professional practice. However, in most instances, field study trips are noncredit-bearing components of modules or are often offered on an optional basis outside teaching hours and considered as 'leisure time' (Freire, op.cit.). In the case study explored in this article, the field trip at the beginning of the third year is integral to the undergraduate programme. It is distinctive because the one-week field study trip abroad is the main component of the module and all the assessments revolve around the trip. It is a unique distinctive feature of our course, which appeals to students.

"The field trip was, in fact, one of the reasons I chose to come and study here, at the University of Sheffield, as it is a great opportunity to see yet another country and how landscape practice works. " 


\section{The students' voice}

Evidence of the students' perception and experience is provided through quotes selected from comments received through an online inquiry emailed to the third-year cohort in the academic year 2016-2017, once the module was completed. The standard post-semester student evaluation forms (mainly a tick-box exercise) do indicate that the module was well received and offer just a few quotes - students rarely add comments to reflect on their experience. The email, an open enquiry sent out after ethical approval, sought specific feedback and included the following prompts:

- What was the most successful learning experience for you?

- Has the field trip changed your view of the course and the profession?

- How did it change your understanding of the relationship between theory and practice?

The resulting responses, representing the views of about a quarter of the student cohort that year, have allowed the students' voice to be embedded in this study - an insight into their understanding and experience of the curriculum.

\section{Student-centred curriculum}

The field study module draws on all the skills and knowledge acquired in the first and second years, but is mainly delivered through hands-on experience outside the university. The informal learning and teaching experience is one of the assets of field trips but the success of that experience depends on the engagement of the participants and encourages involvement through ownership. Ensuring 'a mutually-held purpose' is essential (Rishbeth, op.cit., p.68). For these reasons, the curriculum is designed primarily round self-directed tasks - linked to the field trip experience - rather than lectures, workshops or seminars and design tutorials, which are the dominant features of the landscape architecture course. Support is provided for activities during the trip and for the assignments, but the curriculum is led by students. It is developed applying the principle that the teacher is no longer the instructor and sole agent to deliver knowledge, but, instead, a guide and facilitator.

A student-centred curriculum fits well with the increasing drive towards empowering students and the promotion of more independent and self-directed learning (Merriam, 2001). This approach is more engaging and can be more inspiring (Healey and Jenkins, op.cit.). The module coordinator offers support through resources and guidance. The brief, which provides the structural framework, is introduced and discussed in seminar-style sessions. The module coordinator supports students in their learning, encouraging critical thinking, but also ensuring the application of academic good practice and controlling quality of learning through assessment (Kent et al., 1997). The structural framework is built around various assessed activities to capture the learning outcomes and share the findings. The activities are developed following inquiry-based approaches, providing choices, promoting independence and encouraging students to take responsibility for their learning, making them aware of themselves as learners (Healey and Jenkins, op.cit; B Bressinger and Carfora, 2014). This approach is 
particularly relevant to our students, who are training to be designers and therefore aiming to develop a unique and original style for their work.

The student-centred approaches chosen to deliver the field study trip module are also responding to HE's wider learning and teaching strategy of enhancing students' experience. The more tailored approaches contribute to a more inclusive learning community and celebrate differences and individuality. This includes students' participation in the decision-making process to enhance their experience of the trip and ensure their full engagement with the selfdirected activities. The students are also asked to contribute to the assessment, so as to increase their awareness of the learning and teaching processes, to empower them and to encourage reflection through peer assessment (Falchikov, 2007).

\section{Structure and content}

The main component of the module is a five-day field trip to Europe, in which we explore and critique contemporary issues related to landscape architecture projects.

The aims of the module are:

- to develop students' understanding of contemporary issues and key challenges in European landscape architecture and planning practice;

- to develop a better understanding of how general trends and developments in landscape architecture have been used in specific cultural and spatial contexts;

- to enable students to undertake independent research and exploration on specific projects in the city visited;

- to introduce students to professional practice across Europe.

As a student-centred curriculum, the module promotes a collaborative learning environment that stimulates dialogue between students and the tutor. This includes discussions as well as regular, two-way, student and tutor feedback through presentations during the trip and reviews in the department. It is stressed at the outset that different perspectives must be respected and that individual, personal interpretations and approaches are welcome. Each of the tasks set as assignments promotes experiential learning approaches and draws from learning methods described in literature (Laurillard, 2012). This includes different ways of learning through acquisition using inquiry, independent research and activities, as well as reviewing, analysing and reflecting on experience. The module's learning and teaching principles also draw from Gibbs' principle of "linking the doing and the thinking" (Gibbs, 1988, p.9) and the three steps advocated by Myers and Jones in their (2015) paper providing guidance for "effective use of field trips in educational programming". This is summarised in Table 1. 
Table 1: Field study Trip activities linked to experiential learning theoretical principles

\begin{tabular}{|c|c|c|}
\hline \multicolumn{3}{|c|}{ Field Study Trip Planning Model of Activities } \\
\hline Planning for experience & Increasing awareness & $\begin{array}{l}\text { Reviewing and reflecting } \\
\text { on experience }\end{array}$ \\
\hline Pre trip & During trip & Post trip \\
\hline $\begin{array}{ll}\text { - } & \text { destination choice } \\
\text { - } & \text { preparation } \\
\text { - } & \text { research } \\
\text { - } & \text { documentation }\end{array}$ & $\begin{array}{ll}\text { - } & \text { physical } \\
\text { - } & \text { experience } \\
\text { - } & \text { reflection } \\
\text { - } & \text { exploration } \\
\text { - } & \text { record } \\
\text { - } & \text { analysis } \\
\text { - } & \text { discussion }\end{array}$ & $\begin{array}{l}\text { - } \text { critical thinking } \\
\text { - } \text { reflection } \\
\text { - illustrations } \\
\text { - } \text { communication } \\
\text { - } \text { presentation } \\
\text { - review } \\
\text { - } \text { assessment }\end{array}$ \\
\hline
\end{tabular}

The assessment criteria are constructively aligned with the learning outcomes of the module, which are:

- to develop skills - to collect data, review literature and analyse information- that bridge academic and professional practice outputs;

- to analyse existing landscape projects and reflect on the challenges of "contemporary landscape architecture practice in Europe;

- to experiment with techniques for project research, analysis, synthesis and evaluation through a range of written and visual media to be handed in digitally;

- to develop professional working practices through oral presentations and production of a digital portfolio consisting of original visual material.

The tasks related to the assessment are varied and enable students to explore various skills and demonstrate a wide range of abilities. The assessment of the tasks set in the brief is a recognition and validation of the importance and impact of experiential learning in the delivery of our professional, accredited course. The assessment tools are chosen carefully to emulate the requirements of professional practice and include a digital portfolio - to be uploaded online and a Pecha Kucha-style presentation, both common practices in design-related professions (Forde et al., 2009). Each assignment is assessed, on content and presentation, against the learning outcomes mentioned above and summarised in Table 2, together with the relevant assessment criteria. 
Table 1: Field Study trip assignments and assessment criteria

\begin{tabular}{|c|c|c|}
\hline \multicolumn{3}{|c|}{ Field Study Trip Assessment tasks and criteria } \\
\hline Assignment & Tasks & Assessment criteria \\
\hline $\begin{array}{l}\text { 1. independent } \\
\text { research } \\
\text { document (two } \\
\text { A4 single-sided, } \\
\text { PDF format) }\end{array}$ & $\begin{array}{l}\text { research exercises: } \\
\text { - general issues related to the } \\
\text { urban context e.g. historic } \\
\text { development, social, planning. } \\
\text { - individual specific sites } \\
\text { should include: } \\
\text { - a brief description of the } \\
\text { project (size, type, functions, } \\
\text { clients, designers) } \\
\text { relevant drawings to } \\
\text { understand the project } \\
\text { (location plan, plan, section, sketches) } \\
\text { analytical drawings related to } \\
\text { original conceptual ideas and } \\
\text { design rationale } \\
\text { representative photographs }\end{array}$ & $\begin{array}{l}\text { - the quality of the research carried out on } \\
\text { the general issues and specific sites } \\
\text { related to the destination of the field trip; } \\
\text { the information provided must be from } \\
\text { reliable sources (please, no reference to } \\
\text { Wikipedia or travel guide) } \\
\text { - the extent to which you are able to } \\
\text { communicate the key aspects of the } \\
\text { topic using visual material } \\
\text { - The standard of graphic communication, } \\
\text { including layout of the two A4 pages } \\
\text { following the templates provided } \\
\text { appropriate referencing; source material } \\
\text { that isn't original, including images and } \\
\text { all material obtained from the Internet, } \\
\text { must be properly referenced using the } \\
\text { Harvard referencing system }\end{array}$ \\
\hline $\begin{array}{l}\text { 2. } \text { digital field trip } \\
\text { portfolio } \\
\text { including original } \\
\text { visual materials } \\
\text { produced in situ; } \\
\text { this should not } \\
\text { exceed eight } \\
\text { pages }\end{array}$ & $\begin{array}{l}\text { - } \\
\text { - } \text { scan of your sketch book } \\
\text { sections, perspectives) } \\
\text { - } \text { social analysis with } \\
\text { observation drawings } \\
\text { focusing on 'people' and the } \\
\text { use of the places visited } \\
\text { analytical drawings related to } \\
\text { scale, texture, light and } \\
\text { shade, thresholds } \\
\text { evaluation, thoughts and } \\
\text { personal reflections in sketch } \\
\text { format or short text }\end{array}$ & 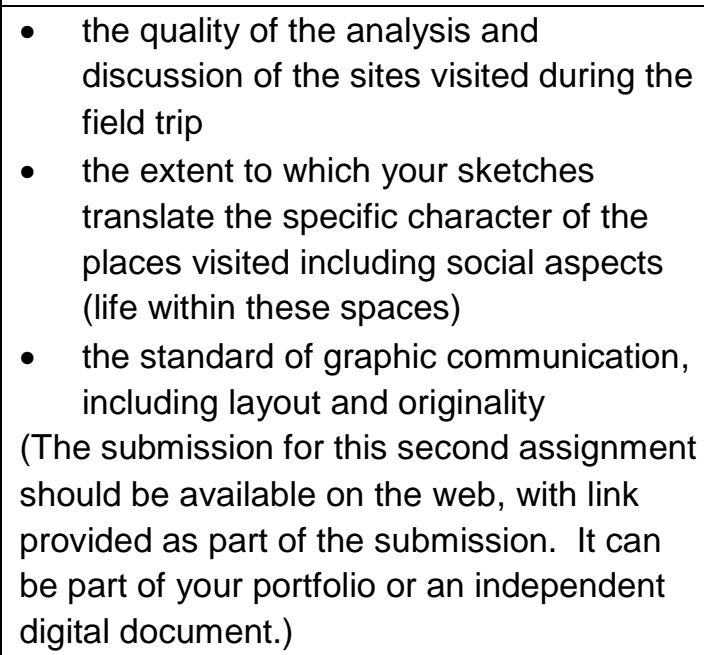 \\
\hline $\begin{array}{l}\text { 3. PowerPoint } \\
\text { presentation to } \\
\text { students in the } \\
\text { department, } \\
\text { Pecha Kucha } \\
\text { style }\end{array}$ & $\begin{array}{l}\text { presentation: two minutes, four } \\
\text { slides }\end{array}$ & $\begin{array}{l}\text { - the choice of the material presented to } \\
\text { convey the character of the place(s) to } \\
\text { the audience } \\
\text { - the quality of the content and delivery of } \\
\text { the oral presentation }\end{array}$ \\
\hline
\end{tabular}

\section{Rethinking student roles: collaboration and engagement}

The field study trip curriculum outside the trip itself is delivered mainly through seminar sessions and self-directed assessed activities designed to empower the students in their learning. Guidance and scaffolding measures are provided to encourage collaboration and facilitate the 
independent learning process, so encouraging the development of skills important to the creation of lifelong learners (Hmelo-Silver et al., 2007). The list of the various tasks included in the module is summarised in Table 3, set against scaffolding measures put in place by the tutor and responding to key principles related to student-led curriculum development.

Table 2: Field study trip activities linked to student-led curriculum principles

\begin{tabular}{|c|c|c|c|}
\hline Stages & Activities and tasks & Scaffolding measures & $\begin{array}{l}\text { Student-led curriculum } \\
\text { principles }\end{array}$ \\
\hline \multirow[t]{2}{*}{ pre-trip } & $\begin{array}{l}\text { choosing destination } \\
\text { - } \quad \text { proposing destination } \\
\text { - } \quad \text { choosing the destination }\end{array}$ & $\begin{array}{l}\text { fixed number of slides for } \\
\text { the PowerPoint } \\
\text { presentation to propose } \\
\text { destinations } \\
\text { - list of required } \\
\text { information: diversity of } \\
\text { landscape architecture } \\
\text { projects; costs within } \\
\text { fixed budget }\end{array}$ & $\begin{array}{ll}\text { - } & \text { empowerment } \\
\text { - } & \text { active involvement } \\
\text { - } & \text { personal initiative } \\
\text { - } & \text { ownership }\end{array}$ \\
\hline & $\begin{array}{l}\text { trip preparation } \\
\text { - Independent research } \\
\text { exercise on a topic or } \\
\text { project related to the } \\
\text { destination of the field } \\
\text { trip } \\
\text { - compilation of all the } \\
\text { research submissions in } \\
\text { one PDF document to } \\
\text { take on the trip }\end{array}$ & $\begin{array}{ll}\text { - } & \text { list of information } \\
\text { required } \\
\text { - } \\
\text { proforma provided for } \\
\text { consistency of final PDF } \\
\text { document }\end{array}$ & $\begin{array}{ll}\text { - } & \text { inquiry-based activities } \\
\text { - } & \text { self-directed learning } \\
\text { - } & \text { collaborative }\end{array}$ \\
\hline \multirow[t]{2}{*}{ trip } & $\begin{array}{l}\text { introduction to places visited } \\
\text { - } \quad \text { students share the } \\
\text { information collected } \\
\text { through their research } \\
\text { exercise; } \\
\text { - } \quad \text { questions and } \\
\text { discussions on site }\end{array}$ & $\begin{array}{ll}\text { - } & \text { time framework } \\
\text { - } & \text { supervision by staff }\end{array}$ & $\begin{array}{ll}\text { - } & \text { cooperative learning } \\
\text { - } & \text { dialogue } \\
\text { - } & \text { peer-assisted learning }\end{array}$ \\
\hline & $\begin{array}{l}\text { exploring - observing - } \\
\text { surveying - mapping and } \\
\text { drawing on site }\end{array}$ & $\begin{array}{ll} & \text { guidance and tutorials } \\
\text { - } & \text { provided by staff } \\
\text { - } & \text { possibilities to ask } \\
& \text { questions } \\
\end{array}$ & $\begin{array}{ll} & \text { independent learning } \\
\text { - } & \text { inquiry-based learning } \\
\text { - } & \text { collaborative learning }\end{array}$ \\
\hline post trip & $\begin{array}{l}\text { develop personal experience } \\
\text { of the field trip in a digital } \\
\text { portfolio } \\
\text { - } \quad \text { reflection } \\
\text { - } \quad \text { analysis } \\
\text { - interpretation } \\
\text { - } \quad \text { documentation } \\
\text { - } \quad \text { representation }\end{array}$ & $\begin{array}{ll}\text { - } & \text { guidance and tutorials } \\
& \text { provided by module co- } \\
& \text { ordinator; } \\
\text { - } & \text { Q and A sessions } \\
\text { - } & \text { group discussions on } \\
\text { exemplars of previous } \\
\text { submissions } \\
\text { - } & \text { peer assessment }\end{array}$ & $\begin{array}{ll}\text { - } & \text { active learning } \\
\text { - } & \text { peer-assisted learning } \\
\text { - } & \text { collaborative learning } \\
\text { - } & \text { independent learning } \\
\text { - } & \text { individual independent } \\
& \text { experience } \\
\text { - } & \text { peer review }\end{array}$ \\
\hline
\end{tabular}




\begin{tabular}{|l|l|ll|l|}
\hline & $\begin{array}{l}\text { Pecha Kucha presentation - } \\
\text { sharing personal experience }\end{array}$ & $\bullet$ & limitation on number of & slides and time \\
and interpretation with the & $\bullet \quad \begin{array}{l}\text { programme and } \\
\text { department learning }\end{array}$ & $\begin{array}{l}\text { organisation } \\
\text { communities }\end{array}$ & $\bullet \quad$ peer assessment & $\begin{array}{l}\text { review } \\
\text { collaborative and } \\
\text { sharing }\end{array}$ \\
\hline
\end{tabular}

A student-centred learning and teaching approach implies greater involvement of students in the delivery of modules. They are given many opportunities to voice their opinions and share their experience. Throughout the module, the students are adopting different roles, as described in the sections below.

\section{Students as decision-makers:}

Collaborating with the students is considered from the outset of the module. Students are asked to make choices and participate to the decision-making process to promote meaningful student involvement. Rather than imposing a destination for the field study trip, they are asked to do their own research and introduce potential destinations to the class through a short presentation, with illustrations of significant landscape architecture projects and a rough costing, including transport and accommodation, in relation to a fixed budget. The module co-ordinator contributes to the discussion and provides additional information whenever possible. The tutor retains the responsibility to veto some destinations, in relation to such non-negotiable issues as safety or cost, because the ultimate responsibility to deliver the trip lies with the department. Following the presentations, the students vote and the destination with the highest number of votes is chosen. Having a role in deciding the destination conveys a sense of ownership, which is valued by students:

"Firstly I think it was very valuable that we had the 'freedom' to choose our own destination and places we want to or should go as landscape architecture students."

\section{Students as co-producers of knowledge:}

Going on a field study trip is a shared experience during which both students and tutors discover and learn new things. Rishbeth (op.cit., p.69) refers to this experience as 'co-learning', which implies more engagement and collaboration in the curriculum delivery - hence the decision to engage the students, pre and post trip, in the production of course reference material.

The first assignment consists of a research exercise on key topics related to the destination and key landscape architecture projects that will be part of the itinerary. The module co-ordinator draws up a list, from which the students choose the topics or places they want to research. Guidance is given on the format to ensure consistency, as this forms the reference document related to the destination, providing knowledge for the participants in the field trip; it is also disseminated to other students in our department, who might wish to undertake an independent study trip to that destination. During the trip, students are asked to introduce the topics they have researched, such as the history of the city, social aspects, planning strategies or a specific landscape architecture project that is part of the programme. These presentations contribute to 
the delivery of the learning outcome, with the students providing the background knowledge and contextual information to complement the exploration in situ. Through the research exercise, they acquire valuable information about the city and places visited; they become the experts. The students can access further information through the written reference document or by asking questions of the student(s) presenting.

The knowledge acquired during the trip is shared more widely through the Pecha Kucha-style presentations during which the third-year students share their personal experience with the rest of the department during two lunchtime seminars. Originally, the rationale for these very short illustrated presentations was to facilitate bottom-up events where designers could share their ideas and passions with others. It is therefore highly appropriate for a student-centred curriculum and has proven to be a "useful presentation style for students" (Miller Beyer, 2011).

\section{Students as professional designers; digital portfolio}

As explained by Mokhtaria (2015), the portfolio encourages active learning and self-reflection and increases the involvement of the learner - principles compatible with the experiential learning approach and, therefore, appropriate to use as the main assessment tool for the study trip module. The student develops her/his portfolio - structured around a topic - from individual experience of the trip, thus using personalised material to disseminate her/his experience, findings, interpretations and personal reflections.

"I think it was also valuable that we could look at specific topics we were interested in, which motivate us to learn by ourselves, instead of learning unilaterally from lectures."

In the context of design professional practices, portfolios are used to demonstrate abilities and style. A portfolio reflects the creativity of its author and showcases her/his work (Forde et al., op.cit.). The choice of a digital submission in the form of a web link is also related to professional requirements, as, in our digital age, publicising skills on line has become a necessity for professional success. The focus is on original illustrations based on drawings produced during the trip. The aim is to encourage students to initiate the process of developing material for their end-of-studies portfolio, which will help them secure their year-in-practice placements, a requirement of our professional, accredited course. This non-standardised assessment method is also a way of celebrating individual personality and personal skills. It promotes 'personal growth' and is particularly valuable for encouraging and stimulating students who are not top academic achievers (Mokhtaria, op.cit.). The more open-ended and lessrestricted approach offers possibilities for using means of expression other than written text - of benefit to our international cohort of students. Through the topic chosen, each student reveals her/his personal interest in and sensitivity to landscape.

"Creating my own brief enabled me to look at the landscape in my own way and this approach allowed me to explore my own topic hands-on through how I individually saw the landscape. This was really beneficial to my understanding especially when looking at how to develop my future projects." 


\section{Students as co-assessors}

Engaging students in the assessment process encourages them to be more responsible and introduces them to the use of assessment criteria and judgement of quality and standard. Involving the students in assessing the quality of the work produced encourages reflection and increases their sense of responsibility within the module (Falchikov, op.cit.). In the field study trip module, the role of the students in the assessment process is directly linked to their personal experience and judgement through the process of voting and attribution of extra points to the mark allocated by the module coordinator. For the research document part of the preparation for the trip, the students are asked to vote for the most useful pages of the reference document and the most informative on-site oral presentation. The voting exercise for the Pecha Kucha presentation at the end of the module involves a larger group, since the lunch time events are advertised widely within the department through posters and email messages. The members of these seminar audiences vote for their favourite presentation, which is given extra points. In the context of a professional, accredited course, the skill of presenting projects efficiently - to client or community groups - is extremely important. Audience perception and appreciation, as reflected in their assessment of an oral presentation, are therefore crucial to a student's development.

(A few students on our course informally raised issues of validity, feeling that there were not enough control measures. This particular concern was addressed by inviting the student-elected year representative to assist the module co-ordinator in the counting process. This ensured transparency and a certain degree of student community ownership of the final result.)

The portfolio is a valuable assessment method, but it does raise issues of comparability (Mokhtaria, op.cit.). A thorough process of moderation is required, to ensure validity and objectivity of the score allocated to this assessment. As part of the introductory seminar, previous-year works are used to facilitate discussions and exploration of this assignment to engage students in the assessment process, but this remains informal. Introducing a more formal peer assessment - whereby students are paired and work together to critique and peerassess their submissions - might be explored. If the pairing were carefully engineered to bring together international and home students, further coherence and integration might well be achieved within the group.

\section{Long-term learning: educational benefits of the field study trip curriculum}

\section{Active and collaborative}

Field study trips break potential barriers and blur differences between the learner and the teacher (Rishbeth, op.cit.). The neutral environment outside the classroom enables the participants to get to know each other better. This can help communication and dialogues, as well as provide an insight into the students' views on the curriculum. It builds cohort cohesion, thus fostering retention and enjoyment throughout the studies. A field trip is a memorable experience, which lasts (Freire, op.cit.). It is stimulating and enables the questioning of concepts and principles through the exploration of places. In the specific field of landscape architecture, it is a unique opportunity to confront the students with real projects and, on some 
occasions, offers the possibility of meeting professionals who can explain their designs and answer questions.

\section{Resilient and dynamic}

One of the main components of the field study trip is travelling to and exploring a European city. This in itself is a learning experience requiring organisation and preparation. It is an opportunity for students of all backgrounds to explore new environments, cultures and traditions. Within the reassuring structure of the daily programme of visits, students are stimulated to engage with exploration, observation and reflection. This is a dynamic process and requires adaptability. The novelty of visiting new places and studying them is a great antidote to the risk of fossilisation of learning and teaching. It is also the best way of grasping the complexity and unpredictability of our changing physical environment. It is also an engaging way of sharing knowledge, as the place of learning is changeable and unpredictable, owing to weather conditions, events and experience. Adaptability and flexibility are skills valued in our changing world. Self-directed learning processes and opportunities for individual decision-making promote resilience, so that students are better equipped to adapt and thrive in practice.

\section{Inclusive}

Our cohort of students has become over $50 \%$ international and issues related to internationalisation are topical in learning and teaching debates. Inclusive approaches are essential and the field study trip is an ideal medium for achieving them, for it provides the opportunity for a "meaningful and mutually supportive experience which is an essential part of the learning process" (De Vita, 2000, p.175). It also fosters "student development of intercultural adaptability" (Voley and Ang, 1998, p.21) For our multicultural cohort, the field trip is a great leveller in a situation where all students are foreigners and do not speak the local language. It is a more egalitarian domain, where cultural differences do not stand out so much and the distinction between 'home' and 'international' becomes redundant. In some cases, international students demonstrate greater confidence as they are often more experienced travellers. Furthermore, being abroad and on unfamiliar territory creates a sense of solidarity within the group and enables greater interaction, especially during free time.

However, the student-centred approach to the field trip module offers challenges to some, as it departs from the more traditional tutor-led model, with which, in their own countries, they might be more familiar (De Vita, op.cit.). There being able to approach the tutor to ask questions in a more informal way and sharing responsibility for information provision may serve to address this issue, by illustrating to less confident students the benefits of participation and contribution. In order to address reticence related to independent learning methods, each activity is carefullystructured and guidance is provided. There is also a contrast in the amount of freedom offered by the two main assignments: the independent research exercise has strict guidance and is structured around a proforma to ensure coherence, whilst the second - post-trip - assignment celebrates individualism by encouraging in each student personal interpretation and reflection, as well as independent style of representation. 


\section{Discussion}

The field study trip module is a good, effective medium for facilitating practical experience and reflective observation, both important to the divergent learning style associated with art-anddesign-related activities (Kolb, 1984). It responds to the need - identified by research into landscape architecture education - for developing strategies for integrating theories and principles with practice (Brown et al., op.cit.; Freire, op.cit.). As demonstrated above, it can be an ideal tool for applying experiential and active learning principles through a student-centred curriculum. The students engage well with collaborative activities such as discussions and peer reviews and the trip itself is a great opportunity to facilitate collaboration. Sharing the experience of a trip abroad is a great team-building activity and the shared memories are a great conduit for discussions and interaction. Such a learning experience of the field study trip empowers students with knowledge that will feed into the rest of their studies and professional experience.

"The field study trip also made me aware of how the theories of urban planning, sustainable housing and ecological design could be applied [...]"

Some students found the student-centred and experiential approach challenging. Those who might lack confidence and motivation do not necessarily welcome principles attached to student-led learning approaches, such as independence, collaboration, peer review and empowerment. For example, in our experience of the first assignment, some did not grasp the importance of their independent research exercise, which was intended as the means of producing a reference document essential to the group as a preparatory introduction to the places the students would visit. The lack of strict instructions for the portfolio also posed problems for some. However, based on the achievements of the students over the three years this module has run, independent learning activities do enable students to build their confidence. This is illustrated by the fact that they successfully complete the module with good marks and stand confidently in front of a wide audience to share their personal experience at the end of the module. It demonstrates that empowerment can build self-confidence and assertiveness, essential qualities for design-related professions.

The module has in general been well received by the students, as reflected in their feedback comments: "I really enjoyed the process and I am happy with the outcome" (international student). A student-centred approach requires greater time investment and effort in preparation, for example to provide explanatory notes and presentations to create the right mindset for students fully to embrace this approach to learning and teaching. It also demands a greater diversity of formative and summative assessments, in order to ensure that all students will be given opportunity to engage successfully, throughout the module, with the process. It is also administratively heavy - for example, the outcome of the votes needs to be processed and the grades changed accordingly. Yet, ultimately, the time investment is worthwhile if it facilitates a transformative, more active approach to learning. It is to be hoped that students will, by following the field study trip module, have gained independence and skills for long-term learning. For some in our department, it has enabled fuller engagement with landscape architecture issues. 
"Through trips I look at and appreciate the landscape in my free time and I can really see how theory has been applied."

"Thoroughly enjoyed the trip abroad - great to have a student-led trip"

The review of the specific experience of the field study trip module illustrates the possibility and potential value - of embracing a more active style of learning and teaching and celebrates experience, exploration and direct involvement. This is particularly beneficial for courses aiming to train future design professionals. Through experiential learning, they are encouraged to adopt a more professional attitude to their studies. The emphasis on shared experience and personal responsibilities is also very helpful in strengthening the identity of the student cohort.

\section{Acknowledgements}

The author acknowledges the help provided by Sally Brown and Clare Rishbeth in preparation of this paper. The author also wishes to thank the two anonymous reviewers for their useful comments and suggestions.

\section{Reference list}

Barrett, T. (2010) 'The problem-based learning process as finding and being in flow.' Innovations in Education and Teaching International 47, 165-17. Available at: https://doiorg.sheffield.idm.oclc.org/10.1080/14703291003718901 (Accessed: 10 November 2018).

Blessinger, P. and Carfora, J.M. (2014) 'Innovative Approaches in Teaching and Learning: An introduction to inquiry-based learning for the arts, humanities, and social sciences.' In: Blessinger, P. and Carfora, J.M. (eds.) Inquiry-Based Learning for the Arts, Humanities, and Social Sciences: A Conceptual and Practical Resource for Educators (Innovations in Higher Education Teaching and Learning, Volume 2). Bingley: Emerald Group Publishing Limited, 3-25. ISBN 1-78441-236-8.

Bishop, J.L. and Verleger, M.A. (2013) 'The flipped classroom: A survey of the research.' ASEE National Conference Proceedings, Atlanta, GA 30(9), 1-18. Available at:

https://www.asee.org/public/conferences/20/papers/6219/view (Accessed: 10 November 2018).

Bonwell, C.C. and Eison, J.A. (1991) Active Learning: Creating excitement in the classroom. San Francisco: Jossey-Bass. ISBN 1-878380-08-7.

Brandes, D. and Ginnis, P. (1986) A Guide to Student-Centred Learning. Oxford: Blackwell. ISBN 0631149333.

Brown, R.D., Hallet, M.E. and Stoltz, R.R. (1994) 'Student learning styles in landscape architecture education.' Landscape and Urban Planning, 30(3), 151-157. Available at: https://doi.org/10.1016/0169-2046(94)90054-X (Accessed:10 November 2018). 
Brown Wright, G. (2011) 'Student-centred learning in higher education.' International Journal of Teaching and Learning in Higher Education, 23, 92-97. Available at:

http://www.isetl.org/ijtlhe/pdf/IJTLHE834.pdf (Accessed: 10 November 2018).

Dewey, J. (1938) Experience and Education. New York: Collier Books. ISBN 0-684-83828-1.

Falchikov, N. (2007) 'The place of peers in learning and assessment.' In: Boud, D. and Falchikov, N. (eds.) Rethinking Assessment in Higher Education. Abingdon: Routledge, 128144. ISBN 0-203-96430-6.

Fenwick, T.J. (2003) Learning Through Experience: Troubling orthodoxies and intersecting questions. Malabar, Florida: Krieger Publishing Company. ISBN 978-1575241968.

Falk, J. and Direking, L. (1997) 'School field trips: Assessing their long-term impact.' Curator, 40, 211-218. Available at: https://onlinelibrary.wiley.com/doi/abs/10.1111//.21516952.1997.tb01304.x (Accessed: 10 November 2018).

Forde, C., Reeves, J. and McMahon, M. (2009) Putting Together Professional Portfolios. Thousand Oaks, CA: Sage Publications Ltd. ISBN 9781412946704.

Freire, M. (2012). Are study trips a leisure time for students and teachers? In I. Dymitryszyn, M. Kaczynska \& G. Maksymiuk (Eds.). Peer Reviewed Proceedings of ECLAS 2012 Conference 'The power of landscape', University of Life Sciences - SGGW, Warsaw, Poland, 19-22 September, 2012, pp. 474-477. ISBN 978-83-935884-0-4.

Gibbs, G. (1981) Teaching Students to Learn: A student-centred approach.Milton Keynes: Open University. ISBN 0335100430.

Gibbs, G. (1988) Learning by Doing: A Guide to teaching and learning methods. London: Further Education Unit. ISBN 1853380717.

Hope, M. (2009) 'The importance of direct experience: A Philosophical defence of fieldwork in human.' Journal of Geography in Higher Education, 33(2),169 -182. Available at: https://www.tandfonline.com/doi/abs/10.1080/03098260802276698 (Accessed: 10 November 2018).

Healey, M. and Jenkins, A. (2000) 'Kolb's experiential learning theory and its application in geography in higher education'. Journal of Geography 99,185-195. Available at: http://dx.doi.org/10.1080/00221340008978967 (Accessed: 10 November 2010).

Hmelo-Silver, C.E., Golan Duncan, R. and Chinn, C.A. (2007) 'Scaffolding and achievement in problem-based and inquiry learning: A response to Kirschner, Sweller, and Clark.' Educational Psychologist, 42(2), 99-107. Available at:

http://www.cogtech.usc.edu/publications/hmelo_ep07.pdf (Accessed: 10 November 2018).

Kent, M., Gilbertson, D. and Hunt, C. (1997) 'Fieldwork in geography teaching: a critical review of the literature and approaches.' Journal of Geography in Higher Education, 2,10-11. Available at: https://www.tandfonline.com/doi/abs/10.1080/03098269708725439url (Accessed:10 November 2018). 
Kolb, D.A., Boyatzis, R.E. and Mainemelis, C. (2000) 'Experiential learning theory: Previous research and new directions.' In: Sternberg, R.J. and Zhang, L.F. (eds.) Perspectives on Cognitive, Learning and Thinking styles. New Jersey: Lawrence Erlbaum, 227-247. ISBN 9780805834314.

Kraft, R. (1990) 'Experiential learning.' In: Miles, J.C. and Priest, S. (eds.) Adventure Education. State College, PA: Venture, 175-183. ISBN 09780910251396.

Kuhn, S. (2001) 'Learning from the architecture studio: Implications for project-based pedagogy.' International Journal of Engineering Education, 17(4 and 5), 349-352. Available at: https://www.scirp.org/(S(czeh2tfayw2orz553k1w0r45))/reference/ReferencesPapers.aspx?Refer encelD=1132181 (Accessed: 10 November 2018).

Laurillard, D. (2012) Teaching as a Design Science. New York: Routledge. ISBN 978-0-203$12508-3$

Maudsley, G. and Strivens, J. (2000) 'Promoting professional knowledge, experiential learning and critical thinking for medical students.' Medical Education, 34, 535-544. Available at: https://onlinelibrary. wiley.com/doi/abs/10.1046/j.1365-2923.2000.00632.x (Accessed: 10 November 2018).

Merriam, S.B. (2001) 'Andragogy and Self-Directed Learning: Pillars of adult learning theory. New Directions for Adult and Continuing Education, 89, 3-14. Available at:

https://onlinelibrary.wiley.com/doi/abs/10.1002/ace.3 (Accessed: 10 November 2018).

Mezirow, J. (2000) Learning as Transformation: Critical perspectives on a theory in progress. San Francisco: Jossey-Bass. ISBN 978-0787948450.

Miller Beyer, A. (2011) 'Improving student presentations: Pecha Kucha and just plain powerpoint.' Teaching of Psychology, 38(2), 122-126. Available at:

https://journals.sagepub.com/doi/10.1177/0098628311401588 (Accessed: 10 November 2018).

Mokhtaria, L. (2015) 'The use of portfolio as an assessment tool.' International Journal of Scientific and Technology Research, 4(7), 170-172. Available at:www.ijstr.org/finalprint/july2015/The-Use-Of-Portfolio-As-An-Assessment-Tool.pdf (Accessed: 10 November 2018).

Myers, B. and Jones, L. (2009) Effective use of field trips in educational programming: A three stage approach. Available at: http://edis.ifas.ufl.edu/pdffiles/WC/WC05400.pdf (Accessed: 10 January 2017).

Nadelson, L. and Jordan, R. (2012) 'Student Attitudes Toward and Recall of Outside Day: An environmental science field trip.' The Journal of Educational Research, 105(3). Available at: https://www.tandfonline.com/doi/full/10.1080/00220671.2011.576715?src=recsys (Accessed: 10 November 2018). 
Owen, C. (2006) 'Design thinking: notes on its nature and use.' Design Research Quarterly, 1(2), 16-27. Available at: https://www.id.iit.edu/wp-content/uploads/2015/03/Design-thinkingnotes-on-its-nature-and-use-owen_desthink071.pdf (Accessed: 10 November 2018).

Prince, M. (2004) 'Does active learning work? A review of the research.' Journal of Engineering Education, 93(3), 223-231. Available at: https://onlinelibrary.wiley.com/doi/abs/10.1002/i.21689830.2004.tb00809.x (Accessed: 10 November 2018).

Rishbeth, C. (2007) Field trips: teaching and learning on the outside. Med dissertation, University of Sheffield, UK.

Slavich, G.M. and Zimbardo, P.G. (2012) Transformational teaching: Theoretical underpinnings, basic principles, and core methods.' Educational Psychology Review, 24(4), 569-608. Available at: https://www.ncbi.nlm.nih.gov/pubmed/23162369 (Accessed: 10 November 2018). 